\title{
The Post-Soviet Puzzle and Western Democracies
}

\author{
Dr. Vladislav V. Froltsov*
}

\section{Introduction}

In the early years of the new millennium, the question of the effective interaction between states from different regions could be estimated as being of signal importance for the foreign policies of all democratic nations because of the significant strengthening of the threats and challenges that face the modern world. While these threats are perhaps of particular concern to the United States, given its role as the world's sole remaining global superpower, they also have an effect on the policies of European nations, which are responsible for the security of many other states within the framework of the world's political and military alliances.

The recent barbaric acts of terrorism in Great Britain and Egypt have clearly demonstrated that the new "International" of the Islamic or non-Islamic radicals is ready to continue a struggle against the democratic nations and their partners despite all the efforts of the global anti-terror coalition. In this dangerous situation, active interaction between the U.S. and its allies must be considered as a key goal for contemporary U.S. foreign policy; this point could be said to be one of the most important messages of the United States' National Security Strategy, published in 2002. ${ }^{1}$ Such policy is also significant for the European countries, including Germany, which is the largest democratic state within the European Union.

The question remains, however, of whether the post-Soviet states will prove to be decisive and trustworthy allies of the Western democracies in this new global conflict, or if this region is bound to transform into the next center of instability. Nowadays this question remains open, but the answer will be of crucial importance both for the foreign policy of Washington and its European allies, and for the future of world politics.

\section{The Emergence of the Post-Soviet World}

The collapse of the USSR and the resulting creation of fifteen post-Soviet states were obvious consequences of the defeat of Moscow in the Cold War. At the same time, the continuing processes in the territory of the former Soviet empire have caused some significant changes in the foreign policy strategies of the Western democracies, particularly of the United States and Germany, which were the most active actors in Eastern European politics.

Over many decades of the twentieth century, the diplomatic strategy of Washington and the European capitals was focused on developing a meaningful interaction with

* Dr. Vladislav Froltsov is an assistant professor of international relations at the Belarusian State University in Minsk. He is a 1999 student of the Marshall Center Leaders Course.

1 The National Security Strategy of the United States of America. September 2002 (Washington, D.C., 2002), 1; available at www. Whitehouse.gov/nsc/nss.pdf; accessed 5 August 2005. 
Moscow. Moreover, all changes (even insignificant) of the political situation in the Kremlin were subject to careful and detailed analysis in the research and intelligence centers of Europe and America. Therefore, it is possible to say that the Soviet leaders were the usual and anticipated partners for the Western democracies until the collapse of the USSR.

But the process of perestroika initiated by Mikhail Gorbachev awakened powerful national-democratic movements in the Soviet republics, which came to power in 198990 in Lithuania, Latvia, Estonia, Armenia, Moldova, and Georgia. In addition to these independence movements, the increasing openness within the Soviet Union fostered the development of influential opposition movements that countered the communist governments of Ukraine, Belarus, Azerbaijan, and some of the republics of Central Asia.

The formation of such political movements represented a real challenge for the foreign policies of Western nations. On the one hand, the United States and European countries welcomed the growth of democracy on the periphery of the Soviet empire and established close contacts with these forces, which were striving without doubt for both economic and political independence from Moscow. But, on the other hand, obvious and permanent support for these opposition movements from Western states had the potential to cause problems personally for Mikhail Gorbachev, who faced a growing counteraction from the hard-liners in the Communist Party and the Soviet security and military structures.

It was a real dilemma for American and European diplomacy in the final years of the USSR (and remained as a challenge for the West in the future as well). This situation can also be identified as one of the main reasons behind the especially careful Western position concerning the de jure recognition of the self-proclaimed independence of three Baltic states and then the other Soviet republics. ${ }^{2}$

Thus, the U.S. and the major European countries recognized the independence of Ukraine only after the final collapse of the Soviet Union in December 1991. ${ }^{3}$ But the Declaration of State Sovereignty, in which this republic was proclaimed "a sovereign national state," was accepted by the Ukrainian Parliament as early as 16 July 1990 (in the period of Gorbachev's final attempts to preserve the unity of the USSR). ${ }^{4}$ This diplomatic recognition did not even come about after a referendum on Ukraine's independence on 1 December 1991, when the decision was approved by more than 90 percent of the voters, despite the clear sympathies of the Western countries to this choice by the Ukrainian people. ${ }^{5}$

2 For more details about this dilemma, see the memoirs (published in Russian) of former ambassadors in the USSR in the perestroika period, Jack F. Matlock, Jr. (U.S.) and Piet Buwalda (the Netherlands): Jack F. Matlock, Smert' imperii (Moscow, 2003), 187 passim; and Piet Buwalda, Dnevnik diplomata (Moscow, 2000), 157, 182-83, 189-90.

3 Hans Georg Lehmann, Deutschland-Chronik 1945 bis 2000 (Bonn: Bouvier, 2000), 507.

4 "Deklarazija pro dershavnyj suverenitet Ukrainy," Bidomosti Verhovnoj Rady URSR 31 (1990): 429.

5 Jack F. Matlock, Smert' imperii (Moscow, 2003), 534-35. 
However, all these efforts on the part of Western leaders were unable to help the final president of the USSR. Mikhail Gorbachev was transformed by Boris Yeltsin and other leaders of the breakaway republics into "a king without kingdom" after the failure of the putsch in August 1991. The new partners of the Western democracies were the governments of the former Soviet republics, which did not always have a clear idea of which path would be the optimum one for their new states to follow.

In this situation, the U.S. and the nations of the EU aspired to assist the new independent states to overcome the numerous problems that they faced regarding their embarkation on a program of social, economic, and political reforms. Concerns about the Soviet nuclear arsenal, which was finally concentrated in Russia as a result of substantial diplomatic efforts on the part of the United States and European countries (as well as significant promises of financial aid), were definitely no less significant. However, the rapid implementation of economic reforms did not result in immediate prosperity in the post-Soviet states, disappointing the expectations of their populations.

Nowadays some experts believe that the level of aid provided by the West was insufficient. ${ }^{6}$ In the early 1990 s, however, the expectations of Western leaders concerning the prospects of the former Soviet Union were very optimistic. They sincerely believed that the end of the Cold War and competition in the military sphere would facilitate a transition to a market economy and a formation of civil society as well as democratic institutions in the former Soviet republics.

As an example of such an idealistic approach, we can consider a position of the former German Chancellor Helmut Kohl, who declared in a special televised statement before the beginning of the process of German unification that the economic problems of the East couldn't be solved in one night, but would be in the "foreseeable" ("überschaubaren") future. ${ }^{7}$ Though it primarily concerned East Germany, this approach was typical regarding all countries of the former "socialist" bloc.

The desire to be "good neighbors"- as well as the aspiration to partnership and cooperation - that dominated global politics in the early 1990s was a reason for the optimism about the rapid integration of the former parts and satellites of the Soviet empire into European and Euro-Atlantic structures. In this period, the efficiency of the foreign policies of the Western countries depended on the success of their participation in efforts to assist the former Soviet republics to achieve conditions of democracy and a market economy. In the case of Helmut Kohl, this aspiration was one of the key elements of the former chancellor's political image, since he considered German foreign policy as an exclusive sphere of his competence. ${ }^{8}$ He also perceived a need to help the

6 See, for example, a highly critical work: Clyde Prestowitz, Rogue Nation. American Unilateralism and the Failure of Good Intentions (New York: Basic Books, 2003), 229.

7 Helmut Kohl, Ich wollte Deutschlands Einheit, assembled by Kai Diekmann and Ralf Georg Reuth (Munich: Ullstein, 2000), 426.

8 Compare with the analysis of Kohl's ruling style in: Stefan Froehlich, "Auf den Kanzler kommt es an": Helmut Kohl und die deutsche Aussenpolitik (Paderborn: F. Schöningh, 2001), $116-17$. 
East as an expression of German gratitude for an opportunity to recreate the united country.

In the 1990s, Germany emerged as a major trading and political partner for the majority of the Eastern European states, including Russia. ${ }^{9}$ Moreover, an active interaction with the post-Soviet states was declared as the logical continuation of Germany's traditional Eastern policy, or Ostpolitik. The Joint Declarations about the Principles of the Relations ("Gemeinsame Erklärungen über die Grundlagen der Beziehungen") that were signed with Latvia (20 April 1993), Estonia (29 April 1993), Ukraine (10 June 1993), and Lithuania (21 July 1993) were viewed as manifestations of the German aspiration to continue such policy. Russia also accepted all legal obligations according to the treaty between Germany and the USSR on Neighborliness, Partnership, and Cooperation ("Vertrag zwischen der BRD und der UdSSR über gute Nachbarschaft, Partnerschaft und Zusammenarbeit"), which was signed by Mikhail Gorbachev and Helmut Kohl in Bonn on 9 November 1990. ${ }^{10}$

Besides these formal relationships, Kohl considered himself to be an advocate ("Sprecher") for the interests of the newly democratic states of Central and Eastern Europe. ${ }^{11}$ He believed that the rapid integration of these states into the EU and NATO would also strengthen Germany's position as a regional leader as well as a model of an effective democracy and social market economy.

For the United States, its relations with the post-Soviet countries were no less significant. However, the world's sole remaining superpower faced a huge number of different problems after the collapse of the USSR that completely changed the configuration of the world political stage. Therefore, any accusation of a political "oversight" concerning the situation in the former Soviet republics, and especially in Russia, is definitely excessive. Moreover, it's possible to agree with the opinion of the German analyst Christian Hacke, who holds that cooperation with Moscow was a priority of U.S. foreign policy during the 1990s, as President Bill Clinton wanted to transform Russia into a key trading and political partner for the U.S. The president considered Russia's transition to democratic politics and a market economy as the main purpose of his policy. Christian Hacke views this approach as a continuation of the idealistic tradition of Woodrow Wilson, Franklin Roosevelt, and Jimmy Carter concerning the United States' foreign policy strategy. ${ }^{12}$ Clinton demonstrated an enduring willingness to help Russia to establish a democratic state during his two terms in office, despite the criticism of the Republican opposition, the skepticism of public opinion, as well as the obvious political and economic problems in Moscow.

9 Werner Weidenfeld and Karl-Rudolf Korte, eds., Handbuch zur deutschen Einheit 19491989-1999 (Bonn: Bundeszentrale für Politische Bildung, 1999), 41.

10 Ibid., 603.

11 Christian Hacke, Die Aussenpolitik der Bundesrepublik Deutschland. Von Konrad Adenauer bis Gerhard Schroeder (Stuttgart: Econ Ullstein List Verlag, 2003), 425-26.

12 Christian Hacke, Zur Weltmacht verdammt (Bonn, Ullstein Verlag, 2003), 547-48. 
Therefore, it is necessary to deny the claim that there was an absence of will on the part of the Western democracies to assist the former parts of the Soviet empire, and that the efforts of the United States and European countries (first of all, Germany) in this regard were insufficient. The most important reasons for the relatively ineffective realization of the optimistic expectations of the West were the social and political heterogeneity of the post-Soviet republics as an element of the modern system of international relations, as well as the dual nature of the foreign policy strategy of many Western democracies towards the newly independent states.

This dual nature was not entirely a result of an incorrect estimation of post-Soviet conditions, but rather a reaction to some controversial tendencies in the foreign policy of the former parts of the USSR. On the one hand, as the largest state that emerged from the wreckage of the Soviet Union, Russia aspired to ensure its status as a regional Great Power as well as a center of attraction for other "fragments" of the Soviet empire. What is more, several post-Soviet countries (for example, Belarus and Tajikistan) acquiesced in this policy. On the other hand, the new independent states strived to keep their distance from Moscow, and their foreign policies were based on the principle: "Our main task is to differ from Russian policy, and to act strictly independently in world politics."

In the case of Ukraine, such a "reflectivity" in their foreign policy in the early 1990s was an object of criticism by the second Ukrainian President Leonid Kuchma (19942005) in his book Ukraina - ne Rossija (translated as "Ukraine is not Russia"). ${ }^{13}$ The first Belarusian ambassador to Germany, Dr. Piotr Sadouski, stated in an interview for the German journal Wostok in 1994 (three years after the creation of the independent Belarusian state) that further interaction between Germany and Belarus depends directly on the dynamics of the relationship between Belarus and Russia. The ambassador underlined the priority placed on German policy towards Moscow in comparison with other post-Soviet countries. ${ }^{14}$

And so it is possible to say that many representatives of the post-Soviet establishment perceived themselves more as the mutinous governors of provinces on the periphery of the Soviet empire than as the leaders of independent states in the first years after the collapse of the USSR. Only three Baltic countries-Lithuania, Latvia, and Estonia-had already formulated a coherent and consistent foreign policy strategy, the purpose of which was a rapid integration into European and Euro-Atlantic structures (this goal was realized successfully in 2004).

Another peculiarity of post-Soviet politics that definitely complicated the development of an interaction with the Western democracies was the excessive expectations of the former Soviet republics, namely their aspiration to rapidly overcome the numerous social, economic, and political problems that they faced with the help of financial aid from the West. In the framework of this view, the United States and European nations were considered primarily as donors that would — or even must—help the post-Soviet

13 Leonid Kuchma, Ukraina - ne Rossija (Moscow: Vremija, 2003), 140-41.

14 "Interview mit Dr. Piotr Sadouski: Deutschland - Belarus. Perspektiven für die Zusammenarbeit," Wostok 1 (1994): 49-51. 
countries to establish market economies and democratic institutions. The U.S. and Germany were seen as the primary engines of this process. Moreover, the economic resources of a unified Germany and its opportunity to assist the former socialist countries were, as a rule, overestimated. ${ }^{15}$

As a result, a sense of mutual disappointment appeared in the late 1990s. Certain social and political developments in Russia and many other post-Soviet countries did not contribute to building optimism in the region. Boris Yeltsin initiated a bloody war against Chechen separatists, which continues to this day. The hard-line communists and nationalists, who dreamed of the revival of the Soviet empire, emerged as the most popular political forces in Russia. The elections were a competition between a so-called "administrative resource" (that is, the use of state power against political opponents during the campaign) and organized criminal structures that were no less powerful.

After a Russian "experience" in October 1993, when Boris Yeltsin violated the constitution, dissolved the parliament, and compelled some of the judges on the Constitutional Court to resign, the heads of many other post-Soviet states successfully repeated this scenario. In the long run, the legislative and judicial bodies in these states were transformed into the appendages of the executive structures. It is remarkable that this process failed in such countries as Ukraine and Moldova, due to a variety of reasons. In the early 2000s, a relatively independent parliament also existed in Georgia. This factor allowed not only the securing, but also the strengthening of the democratic institutions in these post-Soviet republics from 2003-2005.

All these trends were seen in Washington as well as in the European capitals as an obvious refusal by a significant portion of the post-Soviet leaders to take steps to build democratic states and develop market economies. Christian Hacke ascertained, for example, that Bill Clinton's reaction to Moscow's withdrawal from democratic standards was a reorientation of U.S. policy to more intensive interaction with Ukraine and the Caucasian countries. ${ }^{16}$ This new policy caused great deal of irritation in Russia, which began to implement its own version of the Monroe Doctrine towards other former parts of the USSR. The post-Soviet republics were considered in the Kremlin to be so-called "blishnee zarubesh 'e" ("neighboring foreign countries") - that is, a sphere of Russian influence and responsibility, where Moscow did not wish to allow the presence of the interests of other states. Moreover, in the early 1990s the Russian government tried to draw some additional countries in Central and Eastern Europe into this sphere, and namely to prevent the integration of Poland, the Czech Republic, and Hungary into NATO (they joined the Alliance in 1999).

In this difficult situation, the U.S. government wanted to simultaneously take into account the interests of Moscow and support the former Soviet satellites, which feared the revival of Russian imperial ambitions and potential new threats from the East. This approach primarily concerned Poland, whose experience of interaction with Russia had

${ }^{15}$ See, for example, Andrei Zagorski, "Russlands Erwartungen an Deutschland," Aus Politik und Zeitgeschichte, B 1-2 (1997): 46-53.

${ }^{16}$ Hacke, Zur Weltmacht verdammt, 550. 
been particularly painful and destructive for centuries. In addition, Warsaw aspired to play a more active role in Central and Eastern Europe. Poland represented a significant demographic presence (almost 39 million) and a potentially significant economic power (Poland's estimated GDP in 2004 was $\$ 463$ billion), as well as an image as the main "trouble-maker" for the Soviet empire in the 1970s-1980s. ${ }^{17}$

Such activity definitely caused a highly negative reaction in Russia, which feared the creation of an alliance of the new democracies on its western border, which wished to become NATO and EU members, and felt no nostalgia for life within the Soviet empire. ${ }^{18}$ It is remarkable, though, that this "nightmare" was successfully realized in the early 2000s, and nowadays Moscow faces a coalition of its former satellites, extending from Estonia to Georgia, and from the Czech Republic to Ukraine. All these countries are united in their common aspiration to cooperate with the U.S. and Western European countries as closely and intensively as possible, and also to promote the spread of democratic values in other post-Soviet states, including Russia. However, some American experts - even in this favorable situation - believed that the U.S. policy towards Poland and the other new democracies went too far, as it obliged the United States to be responsible for the security of these countries. ${ }^{19}$

In the case of Germany, the effort to support the new democracies in Central and Eastern Europe as well as to simultaneously take into account the interests of Moscow in this region was typical for German foreign policy in the 1990s. It was considered to be a basic element of diplomacy by Hans-Dietrich Genscher and his successor Klaus Kinkel. ${ }^{20}$ They aspired to establish a close interaction between NATO and Russia, and hoped that this partnership could equilibrate the loss of control over their former European satellites for the Russian establishment and society, which suffered from the psychological trauma and humiliation of the collapse of their huge empire.

However, the German government faced a new challenge. Along with Poland, the Czech Republic, and Hungary, the three Baltic states also aspired to join NATO, despite the obvious irritation of Moscow. In this case, Russia's interests in blishnee zarubesh'e were violated immediately, and this certainly contributed to the further deepening of opposition between Moscow and the Western democracies.

Another significant impulse for this process was NATO's military action against the regime of Slobodan Milosevic in Yugoslavia in the spring of 1999. This nationalistic politician was supported indirectly by Moscow. Russia had traditionally declared itself to be a strong defender of the Serbian people, though the USSR kept silent when the

17 CIA. The World Factbook: Poland; available at www.cia.gov/cia/publications/factbook/geos/ pl.html; accessed 6 August 2005.

18 See, for example, a very informative article by Jeremy Page, "Mugging of boys leads to new diplomatic cold war," The Times (London), 4 August 2005; available at www.timesonline.co.uk/article/0,,3-1720237,00.html; accessed 6 August 2005.

19 Prestowitz, Rogue Nation, 164-65, 243-44.

20 Hans-Dieter Heumann, "Genscher, ein 'liberaler' Aussenpolitik?" in Genscher, Deutschland und Europa, ed. Hans-Dieter Lucas (Baden-Baden: Nomos, 2002), 429. 
Nazis attacked Yugoslavia in April 1941, because of the Molotov-Ribbentrop Pact, which was signed in August 1939. Moreover, from 1948-1953, a war between the USSR and Tito's "people's democracy" appeared to be a very real possibility. But the overwhelming majority of the population in Russia and the other post-Soviet countries didn't know about these historical facts, and enjoyed the TV programs from Moscow, which retransmitted as fact all news and comments from Belgrade. Another annoyance to Moscow was the condemnation of Russia's 1999 escalation of the war against the Chechen separatists by the Western democracies; this international opprobrium was especially unpleasant for the Russian government and citizens.

Under such conditions, the German government considered the effort to preserve the interaction between Moscow and NATO as one of the basic elements of a new configuration of European and Euro-Atlantic security to be especially important. ${ }^{21}$ Germany was perceived in Russia as being Russia's main trading and political partner in Europe. Moscow withdrew its troops from the new Eastern Länder (states) of Germany in August 1994, several months ahead of schedule (the stipulated date was 31 December 1994). ${ }^{22}$ Therefore, Boris Yeltsin waited for a demonstration of German gratitude, and namely hoped for a transformation of the country into Russia's main political ally among the Western democracies. However, Helmut Kohl—along with his successor, Gerhard Schröder - actively supported the military operation in Yugoslavia, and also the integration of the former Soviet satellites into NATO, despite all their declarations about building a strategic partnership with Russia.

Besides, the "Red-Green" coalition, which won the federal elections in Germany in September 1998, needed to act urgently to improve the economic situation in Germany, due to the support they garnered from voters from the economically backward areas of Eastern Germany, which still featured a high level of unemployment and many closed factories. ${ }^{23}$ A reduction of governmental spending, including expenditures on foreign policy, was an obvious step. These reductions in spending also affected Germany's payments into the European budget, foreign aid for Russia, and German activities in preparation for a round of EU expansion.

The head of the office of the Konrad-Adenauer-Stiftung in Warsaw, Henning Tewes, characterized the key feature of modern German foreign policy as a fundamental conflict between different goals ("Zielkonflikt"), which he states has existed since the middle of the 1990s. ${ }^{24}$ However, in the late 1990s, when the economic and social

${ }^{21}$ Werner Link, "Ordnungsentwürfe für Europa," in Weltpolitik im neuen Jahrhundert, ed. Karl Kaiser and Hans-Peter Schwarz (Bonn: Bundeszentrale für Politische Bildung, 2000), 56364.

22 Lehmann, Deutschland-Chronik 1945 bis 2000, 509-10.

23 Die Fischer Chronik Deutschland. Ereignisse. Personen. Daten (Frankfurt am Main: Fischer Taschenbuch Verlag, 2001), 1035-36.

${ }^{24}$ Henning Tewes, "Rot-Grün und die Osterweiterung der Europäischen Union," in Deutschland im Abseits? Rot-grüne Aussenpolitik 1998-2003, ed. Hans Maull, Sebastian Harnisch, and Constantin Grund (Baden-Baden: Nomos, 2003), 79. 
crisis in Germany was an obvious phenomenon, the government should have concentrated more efforts on Germany's internal problems. This moment had the potential to either transform Gerhard Schröder into one of Germany's most successful chancellors (if the domestic problems were successfully addressed) or to put an end to his further political career (if the crisis tendencies developed again). The latter scenario was estimated as being the more likely possibility after the Social Democrats' poor performance in the elections in North Rhine-Westphalia on 22 May $2005 .^{25}$

In this period, political developments in Russia began to raise more and more questions. A formal transfer of presidential power from Boris Yeltsin to Vladimir Putin took place at the end of 1999. However, a more significant trend in this period was the final formulation of the new foreign policy vision of the modern Russian establishment. German expert Jutta Scherrer has pointed to a "vestigial imperial idea" ("eine überlebte Reichsidee") as its main principle. ${ }^{26}$ It is possible to name the following basic elements of this "new-old" vision in the sphere of international relations, which had a substantial influence on Russian foreign policy strategy in the early years of the century:

- A peculiar conviction exists in Russia that this country is a separate civilization, which is related neither to the West, nor to the East. It leads to claims for a special Russian role in Eurasia, as well as an aspiration to be a Great Power.

- A feeling that the Ukrainian and Belarusian nations are the "younger brothers" of Russia, and a hope, that these three countries (Russia, Belarus, and Ukraine) will be reunited eventually. In the framework of this vision, the collapsed Soviet Union is considered as the best model for the union of the fraternal nations. The struggle to revive the USSR, even in the form of the union of three Eastern Slavonic states, is a reason for the extremely negative reaction from Moscow concerning the fact that pro-Russian candidate and former Ukrainian Prime Minister Victor Janukovich lost the last presidential elections in this country in January 2005.

- A negative evaluation of all possible alliances of the post-Soviet states that do not involve Russia - for example, GUAM, which includes Georgia, Ukraine, Azerbaijan, and Moldova - which are considered as a threat to its influence in blishnee zarubesh'e. This is accompanied by a fear concerning the close interaction of these countries with the new members of NATO and the EU; such interactions are seen as a real attempt to isolate Russia from Europe.

25 "Wahl zum 16. Deutschen Bundestag am 18 September 2005. Heft 1. Ergebnisse und Vergleichszahlen früherer Bundestags-, Europa- und Landtagswahlen sowie Strukturdaten für die Bundestagswahlkreise" (Wiesbaden, 2005), 94; available at www.bundeswahlleiter.de/ wahlen/download/heft12005gesamt.pdf; accessed 6 August 2005.

26 Jutta Scherrer, "Das Erbe: Geschichte und Gesellschaftskultur," in Russland unter neuer Führung. Politik, Wirtschaft und Gesellschaft am Beginn des 21. Jahrhunderts, ed. HansHermann Höhmann and Hans-Henning Schroeder (Bonn: Bundeszentrale für Politische Bildung, 2001), 79. 
- A tendency to consider the new independent states only as objects of international relations, and namely as a site of the collision between the political interests of Moscow and other countries (the U.S., Germany, Turkey, etc.). A typical example is the position taken by one of the most well-known Russian foreign policy experts, Anatoly Utkin, who promulgated his evaluation of the future role of Ukraine in world politics as "a field of hard struggle" in his four books, which were issued in 2001-2003. ${ }^{27}$ It is quite probable that this statement will be repeated word for word in his further publications.

- A view of the policies of Mikhail Gorbachev, who recognized the independence of Lithuania, Latvia, and Estonia in September 1991, and also the first presidents of Russia and Ukraine, Boris Yeltsin and Leonid Kravchuk, as well as the speaker of the Belarusian parliament, Stanislau Shushkevich, who liquidated the Soviet Union in December 1991, as a betrayal. In the case of Gorbachev, this view is very rare in geopolitical circles. The former head of the state, who is especially respected abroad (particularly in Germany) for putting an end to the exhausting global confrontation that could have erupted into the Third World War at any moment, has an extremely negative rating in his native land. In 1996, less than one percent of the voters supported him as a candidate in the Russian presidential race. $^{28}$

All these tendencies gave a key role to the concept of blishnee zarubesh'e in Moscow's modern foreign policy. The ability to exert control over the former parts of the Soviet empire allows both the Russian establishment and the population to identify themselves as representatives of a Great Power, which, despite the disintegration of the USSR, continues to exist and exert an influence on other states. Moscow used the following methods to realize this policy:

- A use of the Russian-speaking population to exert pressure on the governments of other states. This was especially the case in the Baltic states. After their integration into the EU, these state are obliged to strictly observe the rights of all national minorities, a fact that gives Moscow an opening to consistently accuse Latvia and Estonia of violating the civil rights of their Russian-speaking minorities.

- Providing active support to separatists in countries whose governments do not wish to maintain close connections with Russia. These separatist groups include the self-proclaimed republics of Abkhazia and South Ossetia within Georgian territory, and also Transdnistria within Moldova. In the early 1990s, Moscow tried to

27 Anatoly Utkin, Mirovoj porjadok XXI veka (Moscow: Algoritm, Russkii natsional'nyi fond, 2001), 369; Anatoly Utkin, Vyzov Zapada i otvet Rossii (Moscow: Algorithm, 2002), 536; Anatoly Utkin, Amerikanskaja imperija (Moscow: EKSMO, Algoritm, 2003), 560; Anatoly Utkin, Edinstvennaja sverhdershava (Moscow: Algorithm, 2003), 485.

28 "Yeltsin wins narrow victory in first-round election," CNN.com International (17 June 1996); available at http://edition.cnn.com/WORLD/9606/17/russia.elex/html; accessed 6 August 2005. 
support the Russian separatists in Crimea, but the decisive and tough actions of the Ukrainian government overcame this dangerous situation. ${ }^{29}$

- Exploiting the economic dependence of some post-Soviet states on Russian oil and gas, which allows Moscow to put pressure on countries that do not have their own hydro-carbonic resources. However, in the case of Ukraine and Belarus, the ultimate recipients of the Russian gas shipped through their territories are Germany and other Western European countries. This compels Moscow to take into account the interests of these two states, whose territory is a transit area for this resource.

- A tendency to intervene into the election processes of other states to support the pro-Russian candidates. The most recent examples are Vladimir Putin's personal participation in the campaign of Victor Janukovich in Ukraine in October-November 2004, as well as a media campaign against Moldovan president Vladimir Voronin, who was successfully re-elected in April 2005.

- A consistent striving to preserve the Commonwealth of the Independent States (CIS) as an instrument for the preservation of Russian domination in the post-Soviet space, and also for the creation of new economic and military-political alliances with some former Soviet republics. The recent and most ambitious integration project of Moscow - the United Economic Space (UES), which was to include Russia, Belarus, Ukraine, and Kazakhstan — was actually suspended because of the skeptical position of the new Ukrainian government.

- Exerting partial control over the information space of the former USSR, as the Russian tabloids and television channels are just as popular in some post-Soviet countries (including Belarus) as the national mass media.

- A wish to limit the active interaction of the former parts of the Soviet empire with Western countries, most of all with the United States. Moscow, for example, supported the demand of Uzbek president Islam Karimov that U.S. troops be withdrawn from this country in six months (that is, by February 2005). ${ }^{30}$ The U.S. military presence in Uzbekistan was viewed as an element of an obvious aspiration to force out Russia from Central Asia. It also caused an ambiguous reaction in Moscow concerning a change of the government in Kyrgyzstan in March 2005.

Such actions definitely challenged the policy of the Western democracies towards the post-Soviet states. However, the U.S. and European approaches to the formation of a new strategy regarding Russia and other countries of this region vary widely; Germany can be used as a typical example in this case.

${ }^{29}$ Kuchma, Ukraina - ne Rossija, 500-504.

${ }^{30}$ For more details, see an article by the former British Ambassador in Uzbekistan: Craig Murray, "Why the US won't admit it was jilted," The Guardian (3 August 2005); available at www.guardian.co.uk/comment/story/0,,1541384,00.html; accessed 5 August 2005. 


\section{United States Policy Towards Russia}

Nowadays for the United States, Russia is first of all a partner in the struggle against international terrorism; this fact determines the interaction with Moscow as one of the top priorities of U.S. foreign policy. In spite of the obvious disagreements during the military action of the U.S.-led coalition against Saddam Hussein, and also the long-term cooperation that exists between Moscow and Tehran, the U.S. government wishes and will continue to wish to avoid a transformation of Russia into an opponent. In the modern conditions of the war against terror, the partnership with Russia is of critical importance to the U.S., even if there are many problems involving the practice of democracy and human rights within this country. But this does not mean that Washington will ignore these issues, and will stop criticizing Vladimir Putin's government for its policies towards the media and big business, or its aspiration to put pressure on its neighboring states.

Moreover, a flexible U.S. strategy concerning Russia and other post-Soviet countries allows the United States to interact successfully both with Moscow and members of GUAM, taking into account the obvious desire on the part of Georgia, Ukraine, Azerbaijan, and Moldova to establish a close relationship with the European and EuroAtlantic structures. To help realize this goal, the United States has successively and decisively supported all states in the former Soviet orbit that aspire to create effective democratic institutions and market economies.

This stance took a more active form in 2005 , namely after the democratic change of the government in Ukraine as a result of the people's protests against the falsified results of the presidential election in November 2004. The new Ukrainian democracy was considered in Washington as a key partner of the U.S. in the region, and providing whatever assistance would be necessary to integrate this country into the European and Euro-Atlantic structures as soon as possible can be described as one of the more important goals of current U.S. foreign policy. ${ }^{31}$

In January 2005, the U.S. Congress submitted the concurrent resolution "Congratulating the people of Ukraine for conducting a democratic, transparent, and fair runoff presidential election on December 26, 2004, and congratulating Viktor Yushchenko on his election as President of Ukraine and his commitment to democracy and reform." The U.S. Congress expressed its "strong and continuing support for the efforts of the Ukrainian people and the new Government of Ukraine to establish a full democracy, the rule of law, and respect for human rights. ${ }^{\prime 32}$ In reply, the new President of Ukraine,

31 Celeste A. Wallander, "Challenge \& Opportunity: A U.S. Strategy on Ukraine," The Center on Strategic and International Studies (CSIS), June 2005, 1-4; available at www.csis.org/ ruseura/050628_usstratonukraine.pdf; accessed 9 August 2005.

32 "Congratulating the people of Ukraine for conducting a democratic, transparent, and fair runoff presidential election on December 26, 2004, and congratulating Viktor Yushchenko on his election as President of Ukraine and his commitment to democracy and reform," 6 January 2005, H. Con. Res. 16 and 26 January 2005, S. Con. Res. 7; available at http://thomas.loc.gov/cgi-bin/query/C?c109:./temp/ c1097smxZs and http:/thomas.loc.gov/ cgi-bin/query/C?c109:./temp/ c109zfyNZS; accessed 24 July 2005. 
Viktor Yushchenko, in an address before a joint session of Congress during a visit to Washington in April 2005, declared that he "would like to thank the United States Congress, U.S. presidents George Walker Bush, Bill Clinton, George Bush, and the entire American nation for their invariable respect for Ukraine and their support for Ukraine's democracy." $" 33$

In May 2005, the U.S. Senate submitted a resolution regarding the present state of Georgian-Russian relations, namely "Expressing support for the withdrawal of Russian troops from Georgia." The resolution declared that "the Russian Federation should respect the territorial integrity and sovereignty of the Republic of Georgia," as well as that "the United States should continue to support Georgia in its efforts to negotiate an agreement for ending Russia's military presence in Georgia."”34

The first visit of a U.S. president to Georgia, in May 2005, was also an especially significant event in the history of cooperation between the two countries. In Tbilisi, George W. Bush declared: "We respect Georgia's desire to join the institutions of Europe. We encourage your closer cooperation with NATO. Georgia's leaders know that the peaceful resolution of conflict is essential to your integration into the transatlantic community. At the same time, the sovereignty and territorial integrity of Georgia must be respected - the territorial [sic] and sovereignty of Georgia must be respected by all nations." ${ }^{, 35}$ In this manner he provided his support to the Georgian government in its diplomatic conflict with Moscow. Addressing the President of Georgia, Mikheil Saakashvili, President Bush said: "We look forward to working with you to meet those obligations. NATO is a very important alliance for the United States of America. It's a place where we have our strategic conversations with our transatlantic friends, and we want to help you achieve your objective there." ${ }^{36}$ It could also be interpreted as a state-

33 Victor Yushchenko, "Ukrainian President Yushchenko's Address before Joint Session of U.S. Congress," The Press Office of the President of Ukraine Victor Yushchenko, 6 April 2005; available at www.president.gov.ua/en/news/data/11_173.html; accessed 24 July 2005. "Expressing support for the withdrawal of Russian troops from Georgia," 12 May 2005, S. Res. 139; available at http://thomas.loc.gov/cgi-bin/query/C?c109:./temp/ c109Mph13t; accessed 24 July 2005.

35 "President Addresses and Thanks Citizens in Tbilisi, Georgia," The Communications Office of the President of Georgia, 10 May 2005; available at www.president.gov.ge/ $? \mathrm{l}=\mathrm{E} \& \mathrm{~m}=0 \& \mathrm{sm}=3 \& \mathrm{id}=124$; accessed 24 July 2005 .

36 "Remarks by President Bush and President Saakashvili of Georgia in a Joint Press Availability," The Communications Office of the President of Georgia, 10 May 2005; available at www.president.gov.ge/?1=E\&m=0\&sm=3\&id=126; accessed 24 July 2005 . 
ment of personal support for the Georgian leader, who is a decisive and long-time proponent of Georgia's pro-Western orientation. ${ }^{37}$

In addition to the situation in Georgia, Washington did not forget the problem of the Russian military presence in several other post-Soviet states. So, in March 2005 the U.S. Senate submitted a resolution "Expressing the sense of the Senate about the actions of Russia regarding Georgia and Moldova," which resolved that the United States should "urge Russia to live up to its commitments at the 1999 Organization for Security and Cooperation in Europe (OSCE) Summit in Istanbul regarding Georgia and Moldova." ${ }^{38}$ Taking into account Russian pressure on Moldova during the last parliamentary elections to avoid the re-election of present president Vladimir Voronin, as well as an unwillingness on the part of Moscow to withdraw its troops from the territory of Moldova and Georgia, this resolution was a demonstration of the United States' firm support for these small former Soviet republics.

The reaction of the U.S. concerning the possible vote fraud and infringements during the recent parliamentary elections in the Kyrgyz Republic was also unequivocal and resolute. In February 2005, the U.S. Senate submitted a resolution "Urging the Government of the Kyrgyz Republic to ensure a democratic, transparent, and fair process for the parliamentary elections scheduled for February 27, 2005," which called on

the Kyrgyz authorities to ensure the full transparency of election procedures before, during, and after the 2005 parliamentary elections; the right to vote for all eligible citizens of the Kyrgyz Republic; unimpeded access by all parties and candidates to print, radio, television, and Internet media on a non-discriminatory basis; and the right of opposition parties and candidates to assemble freely, campaign openly, and contest the upcoming elections on an equal basis as all other parties, including the party currently in control of the Parliament.

But the recommendations of the U.S. senators were ignored, and as a result mass protests began in this Central Asian republic, which compelled long-term president Askar Akaev to resign.

Finally, the U.S. Congress declared its position concerning Moscow's unwillingness to recognize the fact of the annexation of the Baltic States in 1940. The special concur-

${ }^{37}$ For more details see the following materials: "Speech delivered by Mikheil Saakashvili at Johns Hopkins University," The Communications Office of the President of Georgia, 4 February 2004; available at www.president.gov.ge/?1=E\&m=0\&sm=3\&id=171; "Speech delivered by President Mikheil Saakashvili at George Washington University," The Communications Office of the President of Georgia, 23 February 2004; available at www.president.gov.ge/?1=E\&m=0\&sm=3\&id=156; "Georgian President addresses nation ahead of Bush visit," The Communications Office of the President of Georgia, 3 May 2005; available at www.president.gov.ge/?1=E\&m=0\&sm=3\&id=156; "President Saakashvili's Welcoming Address for the President of the United States," The Communications Office of the President of Georgia, 10 May 2005; all accessed 24 July 2005.

38 "Expressing the sense of the Senate about the actions of Russia regarding Georgia and Moldova," 10 March 2005, S. Res. 69; available at http://thomas.loc.gov/cgibin/query/C?c109:./temp/ c109udzio8; accessed 24 July 2005. 
rent resolution "Expressing the sense of Congress that the Government of the Russian Federation should issue a clear and unambiguous statement of admission and condemnation of the illegal occupation and annexation by the Soviet Union from 1940 to 1991 of the Baltic countries of Estonia, Latvia, and Lithuania" passed by the Senate on 19 May 2005, and the House of Representatives on 22 July $2005 .{ }^{39}$

As a result of this activity, Washington could present itself as a resolute and firm advocate of the interests of the new post-Soviet democracies, and thereby demonstrate its willingness to strengthen its cooperation with these republics. This trend allows Washington to hope that the next "Kiev" round of EU and NATO enlargement-as predicted by Zbigniew Brzezinski-would be a clear demonstration of the success of the U.S. strategy towards Eastern Europe, which could substantially reinforce the position of this superpower in the modern global arena. ${ }^{40}$

At the same time, in the case of Russia it is necessary to point out that the U.S. government has certainly not been the most "convenient" partner for Moscow during the past several years. But the permanent anxiety in Washington concerning the further political development of Russia can be interpreted, first of all, as a factor of the positive external influences on the largest post-Soviet state.

\section{Germany and Relations with Russia}

For Germany, the maintenance of good relations with the former parts of the USSR is more important than for the United States, taking into account Germany's geographical position and its economic interests in this region. Russia's problems with democracy and human rights, and also the economic and social crises that have roiled the country, have resulted in a serious contradiction in the framework of the German strategy towards Moscow. Gerhard Schröder was able to establish friendly relations personally with Vladimir Putin, but the German Minister for Foreign Affairs, Joschka Fisher, criticized Russia harshly and constantly for the situation in the Chechen Republic and its obvious rejection of many democratic principles. ${ }^{41}$ This contradictory situation resembles the interactions between Moscow and Berlin during the last term of the government of Helmut Kohl. Boris Yeltsin considered him to be his best friend in the West, but, nevertheless, Germany criticized Russia's political development (along with other Western countries). At the same time, though, Germany continued to actively trade with Russia. $^{42}$

As a result, cooperation between Berlin and Moscow concentrated mostly on the sphere of economy and trade, in spite of a temporary rapprochement of the Russian,

39 "Expressing the sense of Congress that the Government of the Russian Federation should issue a clear and unambiguous statement of admission and condemnation of the illegal occupation and annexation by the Soviet Union from 1940 to 1991 of the Baltic countries of Estonia, Latvia, and Lithuania," 19 May 2005 S. Con. Res. 5 and 22 July 2005, H. Con. Res. 128.

Zbigniew Brzezinski, The Choice: Global Domination or Global Leadership (New York:

Basic Books, 2004), 223.

41

42

Christian Hacke, Die Aussenpolitik der Bundesrepublik Deutschland, 466-67.

Ibid., 428-29, 463-65. 
German, and French positions concerning the military action in Iraq. The Federal Republic was interested in gas and other natural resources, and Russia desired a stable market in which to sell them. Both countries took and continue to take into account this interdependence. Therefore, Berlin and Moscow aspire to enlarge the range of their economic cooperation, drawing heavily on the friendly personal relationship that exists between both leaders. ${ }^{43}$

In this context it is remarkable that in at article by Gerhard Schröder, which was published in the Russian journal Rossija v globalnoj politike in July-August 2004, the phrase "Germany is the number one economic partner for Russia" appeared in the second sentence. It characterizes very precisely the vision of Russia that was held by the federal government in Germany in the early years of the new century. ${ }^{44}$

However, the German position regarding other post-Soviet states is more contradictory. As long ago as November 1994, Chancellor Helmut Kohl named Ukraine- together with Russia - as a priority of German foreign policy towards Eastern Europe. ${ }^{45}$ But Moscow remained a major partner for Berlin during all of Helmut Kohl's years in office, as well as those of his successor, Gerhard Schröder. The German government did not wish to intervene in the controversial relations between the post-Soviet states, though the FRG criticized some countries for their poor records regarding democracy and human rights from time to time. ${ }^{46}$

It is also probable that Germany hoped to avoid any negative reaction from Moscow for taking an active policy towards the countries of blishnee zarubesh'e, which was the usual practice for U.S. diplomacy in this region. Instead, the federal government's primary support went to its traditional partners (or even friends) Boris Yeltsin and Vladimir Putin. The same strategy was enacted towards Mikhail Gorbachev before the collapse of the USSR. Moreover, Germany has preferred to interact with these countries, as a rule, within the framework of the common foreign and security policy of the EU, and also together with other European countries, or to participate in UN actions in the post-Soviet space in the recent past, rather than forming direct bilateral relationships

${ }^{43}$ Alexander Rahr, "Pochemy Shroederu nravit'za Rossija," Rossija v globalnoj politike 2:4 (2004): 77, 81-82.

44 Gerhard Schröder, "Rossija i Germanija: leytmotiv sotrudnichestva," Rossija v globalnoj politike 2:4 (2004): 68.

45 Helmut Kohl, Aufbruch in die Zukunft: Deutschland gemeinsam erneuern. Regierungspolitik 1994-1998, Die Regierungserklärung von Bundeskanzler Dr. Helmut Kohl vor dem Deutschen Bundestag am 23. November 1994 (Bonn: Presse- und Informationsamt der Bundesregierung, 1994), 46.

46 Regarding the German position concerning human rights in Ukraine, see, for example: "Verlangsamung des Reformtempos in der Ukraine," hib-Meldung (1 July 2004); available at www.bundestag.de/bic/hib/2004/2004_148/02.html; accessed 24 July 2005. 
with the post-Soviet states. ${ }^{47}$ Therefore it is necessary to agree with the opinion of Christian Hacke, that the Federal Republic of Germany does not have a detailed concept of a policy towards Central and Eastern Europe, even now. ${ }^{48}$ However, such a concept is more than necessary at this moment, since even close cooperation with Moscow is no guarantee of the same friendly relations with other post-Soviet countries, whose foreign policy interests and strategies vary widely.

For example, during his first visit to Germany, the new Ukrainian President Viktor Yushchenko declared his wish to begin the negotiations about the Associated Treaty between Ukraine and the European Union in 2007, to open a way to full EU membership for this post-Soviet country. This proposal was a key element of the Yushchenko's address before the German Bundestag on 9 March $2005 .{ }^{49}$ The reaction of the German government was very cautious and restrained. The president of the Bundestag, Wolfgang Thierse (SPD), welcomed Viktor Yushchenko as an "elected representative of the new, young Ukrainian democracy." ${ }^{50}$ But the question of Ukraine's possible membership in the EU was left without a clear German response.

At the same time, this situation was successfully used by the Christian Democrats to emphasize once again the weakness of Gerhard Schröder's foreign policy. Thus Volker Rühe, the head of the Foreign Policy Committee of the Bundestag and former German Minister of Defense (1992-98), declared, that it is necessary to evaluate whether it would be "a benefit for all Europe" if - thanks to the success of its political reformsUkraine would become a "part of the European Success Story." 51 In addition, the CDU/CSU faction in the Bundestag passed a special statement (15/5021) calling on the German government to work "actively for a closer partnership of the EU and Ukraine," as well as to assist in developing the institutions of a democratic society and market economy, thereby helping to give this land "a clear European perspective."

47 Deutsche Aussenpolitik 2003/2004 (Berlin: Das Auswärtiges Amt, 2004), 83-85, 105, 11114; available at www.auswaertiges-amt.de/www/de/infoservice/download/pdf/publikationen/ ap2004.pdf; accessed 10 April 2005. See also Deutsche Aussenpolitik 2004/2005 (Berlin: Das Auswärtiges Amt, 2005), 59, 65, 76, 112, 155-56, 160; available at www.auswaertigesamt.de/www/de/infoservice/download/pdf/publikationen/ap2005.pdf; accessed 8 August 2005.

48 Christian Hacke, Die Aussenpolitik der Bundesrepublik Deutschland, 560.

49 "Rede von Präsident der Ukraine Viktor Juschtschenko im Deutschen Bundestag," Press Office of the President of Ukraine Victor Yushchenko, 9 March 2005; available at www.president.gov.ua/en/news/data/11_877.html; accessed 24 July 2005.

50 "Ansprache des Staatsoberhaupts der Ükraine, Juschtschenko möchte 2007 Verhandlungen über EU-Beitritt aufnehmen," hib-Meldung (9 March 2005); available at www.bundestag.de/ bic/hib/2005/2005_069/01.html; accessed 24 July 2005.

51 Johanna Metz, "Ein Land will Teil der europäischen Erfolgsstory werden,“ Das Parlament (20 July 2005); available at www.bundestag.de/dasparlament/2005/25-26/europa/002.html; accessed 24 July 2005.

52 "CDU/CSU: Die Ukraine ist ein in jeder Hinsicht europäisches Land," Das Parlament (29 March 2005); available at http://www.bundestag.de/dasparlament/2005/13-14/ plenumundausschuesse/005.html; accessed 24 July 2005. 
Moreover, before the Bundestag elections scheduled for 18 September 2005, the Christian Democrats presented their vision of German foreign policy. One of its elements was a new strategy towards Russia and other post-Soviet countries. The opposition admitted that cooperation with Russia is crucial for the preservation of stability and peace in Europe. The CDU also spoke of the necessity to promote the process of reform in Russia, as well as to develop German-Russian interaction in all spheres. ${ }^{53}$ However, the party condemned Gerhard Schröder for his unwillingness to speak with Vladimir Putin about Russia's problems with democratic values, and namely about the violations of human rights in Chechnya and the persistent government censorship of the media that strengthens the Russian regimes' authoritarian tendencies. The Christian Democrats promised to support the democratic forces in Russia and to assist in establishing a social market economy in this country. ${ }^{54}$ In another document, the "Governmental Program 2005-2009," the opposition coalition declared that they want to have good relations with Russia, but "not over the heads of our neighbors.",55

However, there were no concrete points about a foreign policy strategy towards other post-Soviet countries in both sets of pre-election materials, in spite of the increasingly resolute steps of some of these states (Ukraine, Georgia, etc.) to integrate themselves into structures such as NATO or the EU. Therefore, it is possible to assume that the problem of how to define Germany's new priorities in this region is also a topical one for the Christian Democrats, not only for the "Red-Green" coalition government.

\section{Conclusion}

Unfortunately, current political developments in the former Soviet republics and satellite states do not allow enough time for long-term deliberation on the question of how best to approach relations with Russia and the other former republics of the USSR. The persistent and growing conflict between Moscow (together with some pro-Russian oriented former Soviet republics) and the GUAM members is likely to develop further, and the struggle for control over the territory of the collapsed Soviet empire will perhaps be one of the central topics in Russian politics during the next parliamentary election in 2007 and the presidential race in 2008. These events can be viewed as decisive for the future development of this country, as the popularity of nationalist and imperial appeals is extremely high at present, among all groups of the population. Therefore, this rhetoric will likely be used by both the representatives of the government and their op-

${ }^{53}$ CDU Deutschlands, Deutschland braucht eine kompetente Aussenpolitik, Politik A-Z, Aussenpolitik, 4, 8; available at http://www.cdu.de/doc/pdf/az_aussenpolitik_191104.pdf; ac-

54

55 8 August 2005

Ibid, 13.

CDU Deutschlands, Deutschland Chancen nutzen. Wachstum. Arbeit. Sicherheit. Das Regierungsprogramm 2005-2009 (Berlin: CDU Deutschlands, 2005), 37; available at http://www.regierungsprogramm.cdu.de/download/regierungsprog-ramm-05-09-cducsu.pdf; accessed 9 August 2005. 
ponents from the national-leftist opposition to attract those voters who have been most injured by the dissolution of the Soviet empire.

At the same time, the probability of the nationalist and leftist parties winning a dominant majority in the next Russian Duma is very substantial. The difficulty of legally transferring presidential power to Putin's successor in 2008 is also acute for the Kremlin establishment, taking into account the many significant social and economic problems in Russia. In this situation, the use of the emotional issue of blishnee zarubesh'e in the presidential campaign is likely inevitable. Therefore, Moscow will directly and indirectly support the Belarusian government in its dispute with the United States, Poland, and other European countries, and will also aspire to exert new influence in the Central Asian and Caucasian regions, as well as resist the new "Orange," "Rose," or any other colorful revolutions. It is worthy of note that Russia has already practiced such a policy once in its history, namely in the first half of the nineteenth century, when the Russian Empire struggled against the revolutionary movements in Europe and America within the framework of "the Holy Alliance" (which allied Russia with Prussia and Austria-Hungary). For this reason, it is highly unlikely that future relations between Russia and Ukraine will be entirely smooth and calm, taking into account Moscow's wish to help pro-Russian candidates during the next parliamentary election in Ukraine in 2006.

If such friction does arise, it is likely that Kiev, Tbilisi, and Chisinau will ask the Western democracies for assistance, a request that would be also supported by Poland, the three Baltic countries, and other new EU and NATO members. But Russia is the major economic partner for Germany, as well as one of the important participants of the anti-terrorism coalition led by the United States. Therefore Berlin and Washington should realize the importance of arriving at an especially flexible and sensitive policy that will enable them to support their new allies in Eastern Europe while avoiding isolating Russia. The most important elements for the success of such a policy are the following conditions:

First, the contradictions between the U.S. and some European countries-primarily Germany and France - which arose because of the military action in Iraq must be overcome (there were also other reasons for the conflict as well). The U.S. international relations scholar Robert Kagan warned of this situation even before the beginning of the operation against Saddam Hussein. He also asserted that these transatlantic frictions are dangerous to the modern world. ${ }^{56}$ They are especially negative for the post-Soviet states, taking into account the aspiration of many politicians in these countries to use for their own ends the disagreements between the U.S. and Germany or France, as well as the disconnect between so-called "Old" and "New" Europe. Therefore, it is necessary to agree with the opinion of Philip H. Gordon and Jeremy Shapiro, two American researchers, who have written of the existence of a "Common Agenda" between the United States and Europe in many regions of the world, and in many spheres of activ-

56 Robert Kagan, Macht und Ohnmacht: Amerika und Europa in der neuen Weltordnung (Berlin: Siedler Verlag, 2003), 116-18. 
ity. ${ }^{57}$ They do not directly address the present situation in the post-Soviet space, but it is clear that close interaction between the U.S. and the states of Western Europe is no less significant for this region than it is for the "Greater Middle East."

Second, the dissemination of democratic values is probably a more important task than the provision of economic assistance or diplomatic interaction with the former parts of the USSR. The U.S. practice of "Public Diplomacy" realized this purpose quite effectively during the 1990s-early 2000s. Therefore, the integration of the Baltic countries into the EU and NATO in 2004, along with the present aspiration of the new governments of Ukraine, Georgia, and other post-Soviet countries to build the democracies and market economies, could be seen as an obvious success of the United States' foreign policy strategy towards this region. For Germany, the effective use of "soft power" concerning the former parts of the Soviet empire is still a problem, although Germany does have long experience in political, economic, and cultural interaction with the nations of Eastern Europe to use as a model. In addition, the modern example of German parliamentary democracy and social market economics are very attractive for the postSoviet states. For this reason, it is possible to agree with the German scholar Gerhard W. Wittkämper, who underlined the special role played by Germany in the formation of the European identity, which could serve as a genuine basis for EU unity. ${ }^{58}$

But for the successful realization of this mission, the FRG needs a new "Cultural Policy" towards the post-Soviet countries, which will include not only assistance for a German language study or information support for its own businessmen in this region, but also a more active spreading of democratic values as well as an aspiration to more robustly consider the variety of political systems and social conditions in the former Soviet republics. The German researcher Karl Kaiser has asserted that an active promotion of democracy will be particularly useful for Germany. ${ }^{59}$ In addition, the federal government should have in mind that there are many other candidates for the role of "democratic locomotive" for the post-Soviet countries - for example, Poland or Ukraine, which might wish to enjoy the role as the new center of contemporary Eastern European politics.

Third, the stock phrase post-Soviet space - which I have used very often in this article-should be considered only as a geographical concept, not a political one. Today, this space includes very different countries, ranging from the new members of the EU and NATO (Lithuania, Latvia, Estonia) to Turkmenistan, where there is only one political party, as in the former Soviet Union. This diversity requires an individualized approach to each of the post-Soviet countries that would allow for the more effective realization of the foreign policy goals of the United States, Germany, and other European countries.

57 Philip H. Gordon and Jeremy Shapiro, Allies at War: America, Europe, and the Crisis over Iraq (New York: McGraw-Hill 2004), 199-221.

58 Gerhard W. Wittkämper, Politik im Wandel - Themen der Zeit. Ausgewählte Vorträge 1987 bis 1997 (Münster: Agenda, 1998),

59 Karl Kaiser, "Die neue Weltpolitik: Folgerungen für Deutschlands Rolle," in Weltpolitik im neuen Jahrhundert, 602. 
Another factor that must be appreciated outside the territory of the former Soviet Union is the new status of Russia. Moscow remained a cultural center as well as an important trading partner for the other former Soviet republics, but its position of prominence is not a given for all leaders of the neighboring states nowadays. In the case of such countries as Ukraine, Georgia, or Moldova, the Russian point of view is, as a rule, an object of harsh criticism within these countries. Certainly, this situation complicates the task of Western diplomats and experts, but an underestimation of the diversity of the post-Soviet world could lead to misunderstandings with new allies in this region.

In any case, the development of relations with the former republics of the Soviet Union will create many new challenges for U.S. and European policy. However, the further democratic development of Russia and its neighbors gives the Western democracies an opportunity to have a solid flank of shared values in this region, which is more necessary than ever in the conditions of the intensifying struggle against international terrorism. The United States, Germany, and other European countries currently have a complicated variety of goals and objectives concerning the former parts of the USSR, namely providing support for the new democracies in Eastern Europe, interacting with Russia as a partner within the anti-terror coalition, maintaining close cooperation with all countries of this region in the framework of NATO and PfP activities, and many others. Therefore, a successful solution of the post-Soviet puzzle would allow nations in the West to view the territory of the former Soviet empire not as a "black hole," but as a region of security and peace, where there are the trustworthy allies and partners for the United States and Europe.

$* * * * *$

Postscript: In the beginning of August 2005, there was an emergency involving a Russian mini-submarine in the Pacific Ocean. Due to the help of the navies from Great Britain and the United States (and also Japan), seven Russian sailors were rescued. The government of Russia thanked these countries for their timely help. Such successful interaction allows the assumption that the Cold War actually did come to an end fifteen years ago, and that the Western democracies (as well as Eastern) stand as the major international partners for Russia and other post-Soviet countries. 
THE QUARTERLY JOURNAL

\section{Bibliography}

Hacke, Christian. Die Aussenpolitik der Bundesrepublik Deutschland. Von Konrad Adenauer bis Gerhard Schroeder. Stuttgart: Econ Ullstein List Verlag, 2003.

Hacke, Christian. Zur Weltmacht verdammt . Bonn, Ullstein Verlag, 2003.

Page, Jeremy. "Mugging of boys leads to new diplomatic cold war." The Times (2005).

Prestowitz, Clyde. Rogue Nation. American Unilateralism and the Failure of Good Intentions. New York: Basic Books, 2003.

Zagorski, Andrei. "Russlands Erwartungen an Deutschland." Aus Politik und Zeitgeschichte (1997): 46-53. 